\title{
AURKB wt Allele
}

National Cancer Institute

\section{Source}

National Cancer Institute. AURKB wt Allele. NCI Thesaurus. Code C68593.

Human AURKB wild-type allele is located in the vicinity of 17p13.1 and is approximately 6 $\mathrm{kb}$ in length. This allele, which encodes serine/threonine-protein kinase 12, plays a role in chromosome segregation modulation during cellular mitosis and meiosis. 